\title{
DR. JOÃO PEREIRA MONTEIRO
}

\author{
Notas biographicas
}

João Monteiro é um nome imperecivel nos fastos das academias brazileiras.

Natural do Rio de Janeiro, labutou nesta cidade nas lides commerciaes até que sua decidida vocação litteraria o fez matricular-se no antigo e afamado Collegio D. Pedro II, hoje Gymnasio Nacional, onde um curso brilhante o habilitou á matricula na Faculdade de Direito de S. Paulo, em I 868.

$\mathrm{Na}$ emulação dos exercicios escolares, nas justas da tribuna e da imprensa, desenvolveu notavel actividade de modo que, ao concluir o curso academico, em $18 ; 2$, era um nome acatado por mestres e condiscipulos.

Com grande successo defendeu theses, e doutorou-se em $\mathbf{8} 874$.

Durante dois annos e oito mezes exerceu o cargo de Curador geral de orphãos na I. ${ }^{a}$ Vara do Rio de Janeiro. 
Com extraordinaria distincção, preencheu durante quasi dois annos a Promotoria da capital de S. Paulo.

As suas vistas de ha muito que estavam voltadas paro outro scenario. Oppoz-se a uma vaga de lente substituto da Faculdade de S. Paulo, e por decreto de 2 de Setembro de I 882 , viu, com a nomeação, satisfeito o antigo e justo desideratum. Pouco tempo depois, por decreto de I 5 de Setembro de 1883 , foi elevado a lente cathedratico.

As suas licçōes eram ouvidas com respeito e o encantamento que sua palavra facil thes em. prestava.

A fama do advogado foi-se dilatando, e nos ultimos annos não havia questão forense de vulto que por uma das partes não lhe fosse confiada ou que não tivesse o seu parecer. As revistas juridicas de S. Paulo e o Direito do Rio de Janeiro, estão cheias de razões, pareceres e artigos do douto cathedratico. As consultas affluiam de toda a parte, do Rio de Janeiro, dos juizes e collegas da capital e do interior do Estado, de Estados visinhos e ás vezes de outros remotos.

Merecida era a reputação.

João Monteiro não era sómente uma intelligencia lucida e penetrante, dispunha tambem de largos e variados conhecimentos.

Sua bibliotheca era, dentre as dos advogados de S. Paulo, das mais completas e interessantes. Infatigavel e methodico no estudo, tendo-lhe verdadeiro amor, não havia these ou questão juridica que the fosse estranha e sobre a qual não pu- 
desse discorrer de prompto, com larga erudição. Era um gosto dirigir-se-lhe uma consulta. Não só a satisfazia plenamente, como citava as soluções já porventura dadas anteriormente e os livros que tratavam da questão, um por um, ou fundamentava os principios em que fundava sua resposta, com clareza e irrecusabilidade.

João Monteiro era sobretudo um orador. Dotado de farta mésse de conhecimentos, colhidos em aturadas leituras de todo o genero e em viagem pelo estrangeiro, com facil manejo da lingua portugueza e de outros varios idiomas, imaginoso, de um porte senhoril, com uma dicção fluentissima e clara, da qual o auditorio não perdia uma syllaba, João Monteiro na tribuna era um artista, meigo ou caloroso, torrencial mesmo, conforme as passagens do discurso, imponente com seu vulto erecto encimado por alvissima cabelleira carrée, expressivo no gesto, seductor, na fórma arrojada nas imagens, conceituoso e erudicto. Por um conjuncto de preciosas qualidades, á tribuna deve os seus melhores dias de triumpho. Os seus principaes discursos, proferidos de I 890 a I 806 , foram reunidos em volume em i 897 . Orador querido e festejado da mocidade, sua presença era reclamada nas festividades academicas, seus discursos ouvidos entre ovações, os melhores trechos decorados e citados na tribuna e na imprensa academicas.

Calava muito no espirito dos estudantes o orgulho e enthusiasmo com que em toda parte, na cathedra, nas solemnidades academicas, nos artigos, e publicamente no estrangeiro, se referia 
á Academia de S. Paulo. N'isso estava em grande parte o segredo da sua popularidade entre estudantes, aos quaes distinguia muito em sua casa, na rua, nos bonds, onde os encontrasse, em contraste com a rispidez com que os tratava individualmente dentro das portas da escola. Ao entrar no atrio da Academia, João Monteiro era outro homem; respondia com seccura a qualquer pergunta, mal olhava, ao entrar, para os estudantes, limitando-se a corresponder-lhes friamente ás saudações. Facil era, por cousa minima, passar-lhes uma reprehensão severa.

O estudante perdoava-lhe de boa mente estas mutações e esperava ancioso ser discipulo de João Monteiro, de cujas aulas os seus alum. nos contavam tanta cousa interessante.

E' que, além disso, elle era lente de um anno prestigioso e suggestivo, o quinto.

Não havia departamento do direito cujos arcanos João Monteiro não devassasse, mas a especialidade a que se dedicou mais de perto foi o processo. Foi a sua cadeira durante muitos annos. Esta circumstancia fez com que concentrasse a actividade nesta litteratura nacional com o Curso de Theoria do Processo Civil e Commercial, obra em tres volumes dados a lume de 1899 a I 9oo. Infelizmente a morte colheu-o quando tinha en preparação um quarto volume sobre o Direito das Acções, que remataria o trabalho, cujo valor póde ser aferido pelo exgottamento rapido da edição do primeiro volume e pelo subsidio que nos ultimos annos tem prestado ás ra- 
zões de advogados e decisões dos juizes e tribunaes em todo o paiz.

Enriqueceu tambem a litteratura juridica com uma monographia sobre - O Perjurio, dissertação com que se apresentou a concurso em i882, e que foi reproduzida n' $O$ Direito.

Convidado a inaugurar em 1892 o curso de legislação comparada, produziu a primorosa prelecção que corre impressa,-Da Universalisą̧ão do Direito.

Em collaboração com o Conselheiro Duarte de Azevedo, organisou em 1893, por incumbencia do Governo do Estado, o projecto de Codigo do Processo Criminal de S. Paulo.

Redigiu, por igual e honrosa incumbencia, em I 894, o projecto de Codigo do Processo Civil e Commercial. Ambos ainda pendem de discussão no Congresso do Estado.

São para notar os seguintes trabalhos de sua lavra:

Das sociedades em conta de participaça, dissertação de concurso, 1882, publicada no Direito, vol. 30, pag. 48I, e com razão elogiada pelo Conselheiro Salustiano Orlando, na nota 453, do Cod. Commercial do Brazil, 6. ${ }^{a}$ edição;

Organisação judiciaria, parecer sobre o projecto da organisação judiciaria de S. Paulo, apresentado ao Senado deste Estado, I89 I;

Parecer sobre o projecto n. 250 de 1893 pela Faculdade de Direito de S. Paulo, (refórma do Codigo Penal na Camara dos Deputados), I 893, tra- 
balho este que foi tambem dado á lume na Revista desta Faculdade, vol. 2., I 1894, pag. 9.;

Cosmopolis do Direito, no vol, $3 .^{\circ}$ da Revista desta Faculdade, pag. I43;

A Unidade do Direito, 1900, memoria lida no Congresso Juridico Americano desse anno, no Rio de Janeiro, impressa em S. Paulo na Typ. Industrial e reeditada em parte na Revista desta Faculdade, vol. 8. pag. I 44.

João Monteiro, era extremo partidario da unidade do direito, e os seus brilhantes esforços estão insculpidos no discurso que proferiu em I 880, na collação de gráo aos bachareis desse anno, na já citada prelecção inaugural do curso de legislação comparada, na Cosmopolis do Direito, na referida memoria - a Unidade do Direito, e no artigo - Congressos Internacionaes de Pariz. (Rev. cit. vol. 9, pag. 7).

Deve ainda ser mencionado o parecer sobre os projectos da Universidade dos Drs. Azevedo Sodré e Leoncio de Carvalho, publicado no Diario Official da União e na Revista desta Faculdade, vol. XI, pag. Ir.

Occupou a cadeira de Senador no Congresso Constituinte do Estado, reunido em i 89 I.

$\mathrm{O}$ insigne jurisconsulto foi nomeado Vice-director da Faculdade de Direito de S. Paulo por decreto de 24 de Janeiro de 1893 , e posto em disponibilidade em rgor, por effeito da refórma de ensino dos cursos juridicos, constante do dec. $n$. 3.903 de 12 de Janeiro desse anno. Foi nomeado Director da mesma Faculdade por decreto de 23 
de Agosto de 1903, quando occorreu a morte do venerando Barão de Ramalho.

Neste elevado corpo veio tambem encontral-o a morte em I 8 de Novembro de I904.

Apezar de ter chegado da Europa dias antes com uma arterio-sclerose adiantandissima, e de correr a noticia da gravidade do seu estado, foi uma dolorosa surpreza o seu passamento. A Congregação resolveu por unanimidade de votos comparecer encorpada ao enterro do venerando Director, suspender os trabalhos por oito dias e mandar tirar, a suas expensas o retrato a oleo do fallecido para ser collocado no salão nobre da Faculdade, consignar na acta um voto de profundo pezar e mandar celebrar no setimo dia solemnissimas exequias na cathedral. $O$ corpo de alumnos tomou parte no sahimento funebre, precedido do estandarte da Faculdade.

Com o seu desaparecimento perderam as lettras um grande cultor e a Academia de S. Paulo um dos seus mais brilhantes ornamentos!

J. B. de Oliveira Coutinho. 